\title{
Casuarina equisetifolia, Australian Pine ${ }^{1}$
}

\author{
Michael G. Andreu, Melissa H. Friedman, and Robert J. Northrop ${ }^{2}$
}

\begin{abstract}
Warning: Australian pine is a category I invasive species in Florida, and its possession, transport, and cultivation are strictly prohibited by the Florida Division of Plant Industry.
\end{abstract}

\section{Family}

Casuarinaceae, she-oak or beefwood family

\section{Genus}

Casuarina comes from the Latinized version of the word for "cassowary", in reference to the small branches of this tree that resemble the droopy plumage of the cassowary bird native to Australia.

\section{Species}

The species name equisetifolia is a combination of the Latin root words equi meaning "horse," seti meaning "with bristles," and folia meaning "leaf." A Roman who was referred to as Pliny the Elder used the word equisetum in his writings in $40 \mathrm{AD}$ to denote a horse's tail. Thus, equisetifolia means "horsetail leaf" or "bristle leaf."

\section{Common Name}

\section{Australian pine, beefwood, ironwood, she-oak, horsetail tree}

Although not a pine, this tree is called "Australian pine" because one of its countries of origin is Australia and its tiny leaves tightly pressed to the stem give it the characteristic

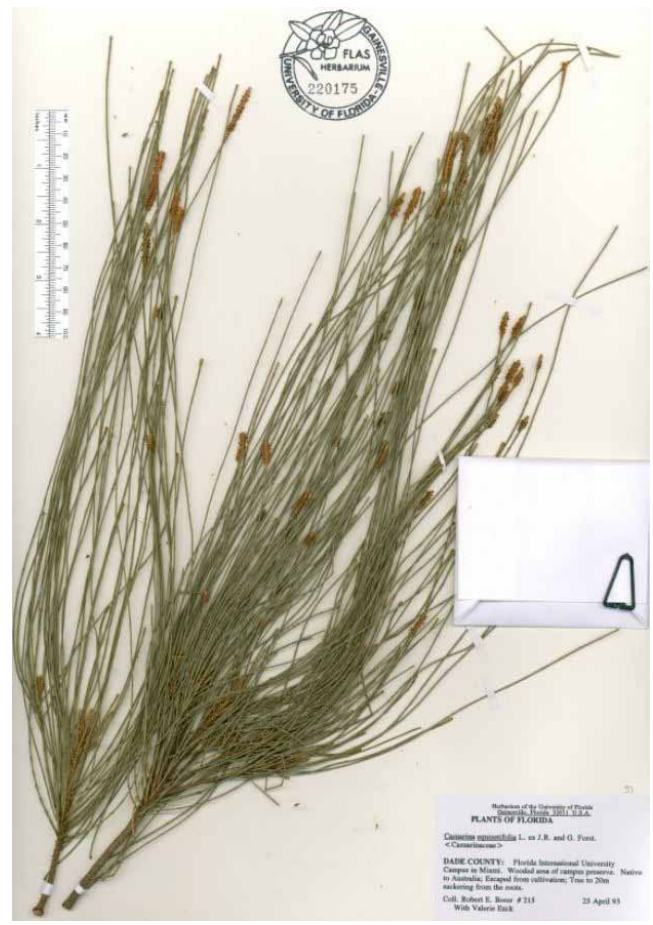

Figure 1. Australian Pine (Casuarina equisetfolia)

Credits: @ UF Herbarium / Josemarly Fleurant

"needle" appearance of a pine tree. In addition, this tree produces small, woody, cone-like structures that resemble a pinecone. Other names associated with this tree include "beefwood" or "ironwood" because it has very dense wood that is difficult to cut or season.

\section{Description}

This evergreen tree is native to Australia, the South Pacific Islands, and Southeast Asia, but it has successfully

1. This document is FOR298, one of a series of the School of Forest Resources and Conservation, Florida Cooperative Extension Service, Institute of Food and Agricultural Sciences, University of Florida. Original publication date July 2012. Visit the EDIS website at http://edis.ifas.ufl.edu.

2. Michael G. Andreu, associate professor; Melissa H. Friedman, research scientist; School of Forest Resources and Conservation; and Robert J. Northrop, Extension forester, Hillsborough County Extension; University of Florida, Gainesville, Florida 32611. 
naturalized in all of Hawaii, Puerto Rico, the Virgin Islands, and in Florida south of Orlando. It has become established and grows vigorously on disturbed sites such as roadsides and filled wetlands, and is commonly seen along coastlines in Florida. Australian pine is salt tolerant and grows well in sandy soil. Thriving in bright, full sunlight, this tree can reach heights of up to 100 feet with a canopy spread of up to 40 feet. A magnifying glass is needed to see the 0.25-inch-long evergreen leaves that press against the 0.03 -inch-diameter stems in a whorled or circular pattern. The bark is red-brown to gray and appears to be constantly peeling from the trunk. The inconspicuous male and female flowers occur on the same tree and bloom twice a year in Florida, first in April and then again in June. The small cone-like structures appear in June and December, producing hundreds of thousands of winged seeds that then disperse with the wind or are eaten by foraging animals that digest and then expel the seed at different locations.

\section{Allergen}

This tree is considered extremely allergenic.

\section{Storm Tolerance}

Australian pine has a very low resistance to wind, causing this tree to be easily damaged during high-wind events, and generally toppling over because of its shallow root system.

\section{Applications}

\section{Commercial/Practical}

In Florida, Australian pine is a prohibited species and, therefore, is not used in commercial applications in the state. However, elsewhere it is sometimes used as a source of pulpwood, and it has been suggested that the wood of this species would make good fuel wood because of its high density and ability to dry quickly.

\section{Cultural}

The bark of Australian pine has been used for medicinal purposes and for tanning leather, while the cones have been used for decorations in locations where the tree is native.

\section{Horticultural}

Australian pine was originally planted in Florida in the late 1800 's as a windbreak and for shade. But by the early 1900's Australian pine was capable of spreading without help from humans. Today it is considered a category I invasive species in Florida, meaning that it is altering native plant communities and is included on the Florida noxious weed list.

As a result, the Division of Plant Industry strictly prohibits possessing (including collecting), transporting (including importing), and cultivating this species. For those who find this tree in close proximity to their home, it's a good idea to replace it with a sturdier, wind-resistant, and non-invasive tree (http://edis.ifas.ufl.edu/pdffiles/FR/FR17300.pdf) since Australian pine is known to have a very low resistance to wind, a particular hazard during tropical storm and hurricane season in Florida. Australian pine is commonly found growing on coastal shorelines since it thrives in salty, sandy environments. However, its shallow root system is not as conducive to preventing soil erosion as other deep-rooted trees native to Florida.

\section{Wildlife}

Birds, especially species of parrots and parakeets not native to Florida, eat thousands of the seeds produced by the Australian pine and assist with the spread of its seed through defecation. Its shallow rooting structure along sandy coastlines makes nesting difficult for sea turtles, the American crocodile, and other beach-nesting reptiles that dig cavities in soil to lay their eggs.

\section{Additional References}

Duever, L. C. (2004). Casuarina equisetifolia. Retrieved from http://www.floridata.com/ref/c/casu_equ.cfm.

Duryea, M., \& Kampf, E. (2007). Wind and trees: Lessons learned from hurricanes (FOR118). Gainesville, FL: UF/ IFAS Florida Cooperative Extension Service. Retrieved from http://edis.ifas.ufl.edu/pdffiles/FR/FR17300.pdf.

Florida Exotic Pest Plant Council (2011). Florida Exotic Pest Plant Council's 2011 Invasive Plant Species List. Retrieved from http://www.fleppc.org/list/list.htm. 